Cezary Mik

\title{
Komunikat Komisji Europejskiej do Parlamentu Europejskiego i Rady Formuła konferencji w sprawie przyszłości Europy ${ }^{1}$
}

\author{
Communication from the European Commission to the European \\ Parliament and the Council: Shaping the Conference \\ on the Future of Europe
}

\begin{abstract}
The European Commission Communication on the Conference on the Future of Europe is a contribution to the inter-institutional discussion on the convening and operation of the Conference and its results. From this perspective, it is a working document, not a final one, which would cause the necessity to take a clear and comprehensive position. In the author's opinion, the draft inter-institutional declaration on the Conference will be of key importance.
\end{abstract}

Keywords: European Union, European Commission

Komunikat Komisji Europejskiej w sprawie konferencji na temat przyszłości Europy jest wkładem w dyskusję międzyinstytucjonalną dotyczącą zwołania konferencji, jej funkcjonowania oraz rezultatów jej działalności. W tym kontekście jest dokumentem roboczym, a nie docelowym, który wywoływałby konieczność zajęcia jednoznacznego i wszechstronnego stanowiska. W ocenie autora kluczowe znaczenie będzie miał projekt deklaracji międzyinstytucjonalnej w sprawie konferencji.

Słowa kluczowe: Unia Europejska, Komisja Europejska

profesor doktor hab. nauk prawnych -

Uniwersytet Kardynała Stefana Wyszyńskiego w Warszawie, Wydział Prawa i Administracji, Katedra Prawa Międzynarodowego i Europejskiego, WARSZAWA, POLSKA •

cezary.mik@sejm.gov.pl, c.mik@uksw.edu.pl • https://orcid.org/0000-0002-6758-1909

\section{Opinia merytoryczna}

\section{Przedmiot dokumentu UE}

\section{- Cel i treść dokumentu UE}

Celem komunikatu Komisji Europejskiej do Parlamentu Europejskiego i Rady Formuła konferencji w sprawie przyszłości Europy (COM(2020) 27 final), zwanego dalej komunikatem, jest wniesienie przez Komisję Europejską wkładu w dys-

1 Opinia na temat komunikatu Komisji Europejskiej do Parlamentu Europejskiego i Rady pt. Formuła Konferencji w sprawie przyszłości Europy (COM(2020) 27 final) sporządzona 21 lutego 2020 r. na zlecenie przewodniczącego Komisji do Spraw Unii Europejskiej; BAS-WAPM-211/20. 
kusję międzyinstytucjonalną o ustanowieniu konferencji w sprawie przyszłości Europy, zwanej dalej konferencją, i ustalenie podstaw jej działania. Konferencja miałaby być odpowiedzią na oczekiwania obywateli Unii, zwłaszcza młodszego pokolenia, co do możliwości wywierania realnego wpływu na kształt i sposób działania Unii Europejskiej (s. 1).

W rozumieniu Komisji konferencja nie jest konferencją międzyrządową, o której mowa w art. 48 Traktatu o Unii Europejskiej, lecz formą uzupełnienia i umocnienia demokracji przedstawicielskiej przez intensyfikację aktywności obywatelskiej i docelowe wzmocnienie powiązań między Europejczykami a instytucjami unijnymi (s. 1, 2, 8). Komisja postrzega bowiem konferencję jako instrument umożliwiający obywatelom i przedsiębiorstwom kształtowanie polityki Unii Europejskiej oraz dający skuteczniejsze kanały komunikacji (s. 8). Chodzi tutaj szczególnie o możliwości wynikające z transformacji ekologicznej i cyfrowej. Ponadto w komunikacie napisano: „Polityka ta musi też służyć rozwiązaniu problemu braku pełnego równouprawnienia oraz zapewnić, aby Unia Europejska stała się sprawiedliwą, zrównoważoną i konkurencyjną gospodarką. Idąc tą drogą, musimy pokazać, że Europa może być bardziej asertywna i może propagować swoje wartości i standardy na całym świecie” (s. 1).

Komisja postrzega konferencję jako nowe forum publiczne, umożliwiające „otwartą, pluralistyczną, przejrzystą i ustrukturyzowaną debatę z obywatelami” forum oddolne, ale mające odzwierciedlać różnorodność Europy, otwarte „na społeczeństwo obywatelskie, instytucje europejskie i inne organy europejskie, w tym Komitet Regionów, Europejski Komitet Ekonomiczno-Społeczny, a także władze krajowe, regionalne i lokalne, parlamenty i inne zainteresowane strony", oraz działające na zasadzie równości partnerów i równych szans udziału wszystkich Europejczyków (s. 2, 5).

W ujęciu Komisji podstawą działania konferencji powinna być deklaracja międzyinstytucjonalna, przygotowana przez Parlament Europejski, Radę i Komisję Europejską. Jednak Komisja na tym tradycyjnym formacie nie poprzestaje. Stwierdza bowiem, że deklaracja taka powinna „być otwarta dla innych sygnatariuszy, w tym także dla instytucji, organizacji i zainteresowanych stron. Im szerzej deklaracja będzie znana, tym lepiej" (s. 8). Treść deklaracji powinna obejmować: koncepcję, zakres, format, strukturę, cele i harmonogram konferencji (s. 8).

W komunikacie wskazano dwa podstawowe zakresy działań konferencji materialny i instytucjonalny. Pierwszy z nich miałby wynikać z programu strategicznego Rady Europejskiej na lata 2019-2024² oraz z priorytetów politycznych obecnej Komisji ${ }^{3}$. Powinny go zatem wyznaczać następujące zagadnienia:

2 A New Strategic Agenda 2019-2024, https://www.consilium.europa.eu/media/39914/a-new-strategic-agenda-2019-2024.pdf [dostęp 20 lutego 2020 r.].

3 Unia, która mierzy wyżej. Mój program dla Europy, program polityczny kandydatki na przewodnicząca Komisji Europejskiej Ursuli von der Leyen. Wytyczne polityczne na 
1) walka ze zmianami klimatu i wyzwania środowiskowe; 2) gospodarka służąca ludziom; 3) sprawiedliwość społeczna i równość; 3) transformacja cyfrowa Europy; 4) promowanie wartości europejskich; 5) zwiększanie znaczenia Unii Europejskiej na arenie międzynarodowej; 6) umacnianie podstaw demokratycznych Unii. Kwestie te nie stanowią zamkniętego katalogu. W zakresie spraw instytucjonalnych konferencja powinna zająć się procesami demokratycznymi i zmianami instytucjonalnymi, co oznacza przede wszystkim konieczność przeprowadzenia analizy systemu czołowych kandydatów w wyborach przewodniczącego Komisji Europejskiej oraz ponadnarodowych list w wyborach do Parlamentu Europejskiego.

Komisja uznała, że konferencja powinna wykorzystać dotychczasowe doświadczenia dotyczące komunikacji z obywatelami Unii (m.in. tzw. dialogi obywatelskie, europejski panel obywatelski na temat przyszłości Europy, wizyty członków Komisji w parlamentach narodowych i regionalnych, zgromadzenia obywateli państw członkowskich), a zarazem zintensyfikować działania informacyjne skierowane do obywateli, „zwłaszcza poza stolicami”. W tym celu należy korzystać $\mathrm{z}$ istniejących narzędzi komunikacji, takich jak europejska inicjatywa ludowa, konsultacje publiczne na portalach internetowych czy programy unijne (np. „Erasmus”) (s. 3-4). Komisja uważa również, że trzeba podnieść dialog obywatelski na wyższy poziom. Proponuje zatem: tematyczne panele dyskusyjne (także bardziej zdecentralizowane), korzystanie z wielojęzycznej platformy cyfrowej ${ }^{4}$, wydarzenia organizowane przez partnerów lokalnych, regionalnych i krajowych, w tym wydarzenia sportowe czy festiwale (s. 4-5).

Sukces konferencji Komisja uzależnia od jakości (skuteczności, szerokości) podejmowanych działań informacyjnych (s. 5-6). Zależy jej na zaangażowaniu instytucji i innych organów Unii, a także na udzieleniu konferencji odpowiedniego wsparcia finansowego. Podkreśla ponadto znaczenie jednolitej identyfikacji wizualnej konferencji i potrzebę kompleksowego podejścia instytucjonalnego do komunikacji, łącznie z wykorzystaniem „terenowych” agend instytucji i organów. W komunikacie położono nacisk na informowanie ludzi młodych i używanie platform cyfrowych. Podkreślono też wagę przejrzystości w komunikacji.

Duże znaczenie przypisano także działaniom, które powinny być podejmowane w odpowiedzi na opinie formułowane przez obywateli Unii. Nowatorstwo

następną kadencję Komisji Europejskiej (2019-2024), s. 5 i n., https://ec.europa.eu/ commission/sites/beta-political/files/political-guidelines-next-commission_pl.pdf [dostęp 20 lutego 2020 r.].

4 Celem funkcjonowania platformy byłoby zapewnienie obywatelom Unii jak najszerszego udziału w konferencji oraz jak największej dostępności i przejrzystości działań konferencji przez: 1) publikowanie wszystkich dokumentów związanych z konferencją oraz omawianych w jej ramach tematów; 2) debaty na żywo; 3) gromadzenie wyników debat w jednym miejscu; 4) promowanie innych interaktywnych sposobów przeprowadzania debat publicznych w ramach konferencji. 
konferencji ma polegać właśnie na zapewnieniu demokracji ciągłego charakteru, a ujmując to bardziej konkretnie - na przekazywaniu obywatelom rezultatów działań podejmowanych w reakcji na ich postulaty. W komunikacie wymieniono m.in. następujące formy działania: „sprawozdania przedstawicielstw Komisji, badania opinii publicznej na konferencjach oraz monitorowanie przez ekspertów dyskusji w internecie i mediach społecznościowych". Sama Komisja mogłaby przedstawiać swoje sprawozdania co kwartał, a także przekładać informacje zwrotne od obywateli na zalecenia i projekty prawodawcze (s. 7).

W komunikacie zaproponowano, aby konferencję rozpocząć w 2020 r. w Dniu Europy, tj. 9 maja (przypadają wówczas dwie rocznice - 70. rocznica podpisania deklaracji Schumana i 75. rocznica zakończenia II wojny światowej), a zakończyć w pierwszej połowie 2022 r. (podczas prezydencji francuskiej). Wówczas należałoby przedstawić efekty jej funkcjonowania i zalecenia wynikające z jej prac, a także rozważyć kolejne kroki. Dla Komisji szczególnie ważne jest określenie działań następczych. Zobowiązanie w tym zakresie powinno być określone we wspólnej deklaracji tworzącej podstawy konferencji (s. 7).

\section{- Geneza dokumentu UE}

Koncepcja konferencji wpisuje się w ciąg działań rozpoczętych jeszcze przez Komisję w poprzednim składzie, a zmierzających do przeprowadzenia kolejnej reformy Unii Europejskiej ${ }^{5}$.

Komunikat jako dokument skierowany do Parlamentu Europejskiego i Rady (nawet nie do Komitetu Gospodarczego i Społecznego ani do Komitetu Regionów) jest elementem dyskusji międzyinstytucjonalnej na temat przyszłości Europy ${ }^{6}$. W tym znaczeniu koresponduje on z konkluzjami Rady Europejskiej z 12 grudnia 2019 r., w których podjęto decyzję polityczną w sprawie konferencji i zobowiązano prezydencję chorwacką do podjęcia prac nad stanowiskiem Rady Unii Europejskiej „co do tematyki, zakresu, składu uczestników i funkcjonowania takiej konferencji”" , oraz z rezolucją Parlamentu Europejskiego z 15 stycznia

5 Zob. m.in. C. Mik, Opinia na temat komunikatu Komisji Europejskiej zatytułowanego Biała księga w sprawie przyszłości Europy. Refleksje i scenariusze dla UE-27 do 2025 [COM(2017) 2025 final], „Zeszyty Prawnicze” 2017, nr 2(54), s. 73 i n. Zob. też prace dotyczące przyszłości Europy po wydanym komunikacie (2017-2019): https:// ec.europa.eu/info/strategy/future-europe_pl [dostęp 20 lutego 2020 r.].

6 Zob. też: M. Skrzyńska, Notatka informacyjna na temat Konwencji w sprawie przyszłości Europy, Biuro Spraw Międzynarodowych Kancelarii Sejmu, 24 stycznia 2020 r., s. 18; Conference on the Future of Europe 2020-2022 (News, Overview), https://www. europeansources.info/record/conference-on-the-future-of-europe-2020-2022 [dostęp 20 lutego 2020 r.].

7 Konkluzje Rady Europejskiej z dnia 12 grudnia 2019 r., pkt 14-16, https://www.consilium.europa.eu/media/41787/12-euco-final-conclusions-pl.pdf [dostęp 20 lutego 2020 r.]. 
2020 r. w sprawie stanowiska Parlamentu Europejskiego dotyczącego konferencji w sprawie przyszłości Europy (P9_TA-PROV(2020)0010) ${ }^{8}$.

Według ustaleń Rady Europejskiej konferencja miałaby rozpocząć się w 2020 r., zakończyć w 2022 r. (podczas prezydencji francuskiej) i powinna przyczyniać się do rozwoju polityk unijnych w średnim i długim okresie, a jej działania powinny być prowadzone z myślą o wyzwaniach, przed którymi stoi Unia. W konkluzjach Rady Europejskiej podkreślono, że dla funkcjonowania konferencji znaczenie mają doświadczenia wynikające $\mathrm{z}$ dialogu $\mathrm{z}$ obywatelami. Ona także powinna opierać się na szerokich konsultacjach $\mathrm{z}$ obywatelami, a ponadto na pełnym zaangażowaniu trzech instytucji: Parlamentu Europejskiego, Rady i Komisji (przy pełnym poszanowaniu równowagi instytucjonalnej i ról tych instytucji określonych traktatowo). Wszystkie państwa członkowskie powinny uczestniczyć w niej w równym stopniu, w poczuciu współodpowiedzialności.

Z kolei w rezolucji Parlamentu Europejskiego podkreślono, że powinien on, jako jedyny organ wybrany bezpośrednio przez obywateli Unii, odgrywać główną rolę w procesie jej reformy. Wskazano też m.in., że istnieje konieczność rozwiązania problemów wewnętrznych i zewnętrznych Europy oraz sprostania wyzwaniom społecznym i ponadnarodowym nieprzewidzianym $\mathrm{w}$ traktacie $\mathrm{z}$ Lizbony („[...] liczba poważnych kryzysów nękających Unię wskazuje na konieczność reform w wielu obszarach zarządzania”). Według Parlamentu Europejskiego „konferencja stanowi okazję do określenia mocnych stron Unii i obszarów wymagających poprawy, aby zwiększyć zdolność Unii do działania i nadania jej bardziej demokratycznego charakteru; [...] celem konferencji powinno być przyjęcie podejścia oddolnego do bezpośredniego angażowania obywateli w konstruktywny dialog, a także [...] w dłuższej perspektywie należy utworzyć stały mechanizm angażowania obywateli w rozważania nad przyszłością Europy" (pkt 2).

Parlament Europejski uznał, że działania konferencji powinien poprzedzać etap wysłuchania obywateli Unii, aby mogli oni „podzielić się swoimi pomysłami, sugestiami i zaproponować własną wizję tego, co oznacza dla nich Europa" (pkt 3). Udział obywateli w konferencji powinien odzwierciedlać różnorodność społeczeństw państw członkowskich, dlatego aby można było objąć dialogiem „wszystkie zakątki Unii”, należy skorzystać z najbardziej skutecznych narzędzi (platform cyfrowych) (pkt 4). Działania konferencji powinny mieć charakter inkluzywny i przejrzysty. Ich najważniejszym wyróżnikiem powinno być „zaangażowanie obywateli, zorganizowanego społeczeństwa obywatelskiego i wielu

8 http://www.europarl.europa.eu/doceo/document/TA-9-2020-0010_PL.html [dostęp 20 lutego 2020 r.]. Zob. też obszerne omówienie prac prowadzonych w Parlamencie Europejskim w celu przyjęcia rezolucji (w trakcie debaty poprzedzającej jej uchwalenie): M. Skrzyńska, op. cit., s. 3-11. Istotny jest fakt, że kształt rezolucji nadało uzgodnienie pięciu frakcji, tj.: chadeckiej (EPP), socjalistycznej (S\&D), liberalnej (RE), Zjednoczonej Lewicy Europejskiej - Nordyckiej Zielonej Lewicy (GUE/NGL) i Zielonych (G/EFA). Rezolucja została przyjęta przede wszystkim ich głosami. 
zainteresowanych stron na szczeblu europejskim, krajowym, regionalnym i lokalnym" (pkt 5).

Wstępnie określonym przedmiotem pracy konferencji, według Parlamentu Europejskiego, powinny być następujące zagadnienia: 1) wartości europejskie, prawa podstawowe i wolności; 2) demokratyczne i instytucjonalne aspekty UE; 3) wyzwania środowiskowe i kryzys klimatyczny; 4) sprawiedliwość społeczna i równość; 5) gospodarka i zatrudnienie, w tym kwestia podatków; 6) transformacja cyfrowa; 7) bezpieczeństwo i rola UE na arenie międzynarodowej. Planując program i debaty w ramach konferencji, należy wykorzystać wyniki specjalnego badania Eurobarometru (pkt 7). Ponadto w agendzie konferencji powinny się znaleźć „system czołowych kandydatów i listy międzynarodowe, z uwzględnieniem istniejących terminów i przy wykorzystaniu wszystkich dostępnych narzędzi międzyinstytucjonalnych, politycznych i ustawodawczych" (pkt 8).

Parlament Europejski zarysował kształt organizacyjny konferencji. Uznał, że powinna ona składać się „z szeregu podmiotów o różnym zakresie obowiązków, takich jak: zgromadzenie plenarne konferencji, agory obywatelskie, agory młodzieżowe, komitet sterujący oraz wykonawcza rada koordynacyjna”, zrównoważonych pod kątem płci (pkt 10). Zgromadzenie plenarne powinno obejmować: 1) 135 członków Parlamentu Europejskiego, przy zachowaniu zrównoważonej reprezentacji politycznej; 2) 27 członków Rady na szczeblu ministerialnym; 3) od 2 do 4 członków z każdego parlamentu narodowego, przy zachowaniu zrównoważonej reprezentacji politycznej; 4) 3 komisarzy z Komisji Europejskiej; 5) po 4 przedstawicieli Europejskiego Komitetu Ekonomiczno-Społecznego i Komitetu Regionów; 6) 2 przedstawicieli organizacji pracodawców i 2 przedstawicieli związków zawodowych (pkt 14, 16). Parlament Europejski zaproponował też, aby w trakcie konferencji odbyło się kilka agor tematycznych (reprezentatywnych geograficznie i pod względem płci, wieku, statusu społeczno-gospodarczego i wykształcenia uczestników) ${ }^{9}$, w których wzięłoby udział po 200-300 obywateli, wybranych losowo przez niezależne instytucje państw członkowskich i działających na zasadzie konsensusu (pkt 10,11), a ponadto co najmniej 2 agory młodzieżowe (pkt 13). Agory powinny mieć możliwość przedstawienia zgromadzeniu wniosków ze swoich prac (pkt 15). Komitet powinni tworzyć przedstawiciele Parlamentu (wszystkie reprezentowane grupy polityczne, a także przedstawiciel Komisji Spraw Konstytucyjnych i przedstawiciel Prezydium Parlamentu Europejskiego), Rady (prezydencje UE) oraz Komisji (3 właściwych komisarzy), przy zachowaniu równowagi politycznej i instytucjonalnej oraz równości podmiotów wchodzących w skład komitetu (pkt 22). Zadaniem komitetu powinno być „przygotowanie posiedzeń zgromadzenia plenarnego konferencji (sporządzanie porządków obrad, sprawozdań z posiedzeń plenarnych i wniosków), jak również

W agorach obywatelskich nie będą mogli uczestniczyć wybrani politycy, wysocy rangą przedstawiciele rządów i przedstawiciele interesów zawodowych (pkt 11). 
agor obywatelskich i młodzieżowych oraz nadzór nad działaniami i organizacją procesu konferencji” (pkt 23). Wreszcie wykonawczą radę koordynacyjną powinni tworzyć przedstawiciele trzech instytucji pod kierownictwem Parlamentu Europejskiego (członkowie rady powinni być członkami komitetu sterującego). Rada powinna odpowiadać „za codzienne zarządzanie procesem konferencji, w szczególności za praktyczną organizację konferencji, grupy robocze, agory obywatelskie i wszelkie inne inicjatywy określone przez komitet sterujący" (pkt 24). Konferencję powinien też wspomagać sekretariat, złożony z osób zatrudnionych w trzech instytucjach (pkt 25).

Zdaniem Parlamentu Europejskiego konferencja powinna odbywać co najmniej dwa razy w ciągu półrocza sesje plenarne (na pierwszym posiedzeniu powinna przyjąć plan prac, a po każdym posiedzeniu udostępniać uczestnikom i opinii publicznej sprawozdanie $\mathrm{z}$ wnioskami oraz sprawozdania grup roboczych). Wnioski końcowe z prac należałoby przyjąć na ostatnim posiedzeniu plenarnym (pkt 17). Konferencja powinna odbyć sesje przygotowawcze i otrzymać szerokie wsparcie ze strony „uznanych i doświadczonych organizacji społeczeństwa obywatelskiego i innych ekspertów". Parlament Europejski podkreślił bowiem „znaczenie wiedzy fachowej organizacji pozarządowych, uniwersytetów, ośrodków badawczych i ośrodków analitycznych w całej Europie" (pkt 18). W dyskusje na temat przyszłości Europy należy też zaangażować przedstawicieli państw kandydujących do Unii (pkt 19). Posiedzenia konferencji powinny być transmitowane $\mathrm{w}$ internecie i otwarte dla publiczności, a dokumenty dotyczące jej działania publikowane (pkt 27). Rezultatem prac konferencji powinny być konkretne zalecenia, „które będą musiały zostać uwzględnione przez instytucje i przekształcone $\mathrm{w}$ działania w celu spełnienia oczekiwań obywateli i zainteresowanych stron po dwuletnim procesie i debatach" (pkt 29). Działaniom następczym należy nadać formę np. konkretnych projektów legislacyjnych lub zmian w traktatach (pkt 31).

Swoje stanowisko w sprawie konferencji przyjęły także niektóre komisje do spraw Unii Europejskiej parlamentów narodowych (np. duńskiego, litewskiego, wspólne stanowisko przewodniczących komisji Zgromadzenia Narodowego i Bundestagu ${ }^{10}$ ). Wreszcie swoją opinię przedstawiła kilkakrotnie $\mathrm{COSAC}^{11}$. Pierwsze działania podjęto również w ramach Rady Unii Europejskiej (COREPER I, prezydencja chorwacka $)^{12}$.

W kontekście prowadzonych dyskusji zarówno w Parlamencie Europejskim, jak i poza nim warto podnieść, że ujawniają one dość daleko idące różnice poglą-

10 Zob. Conference on the Future of Europe Franco-German non-paper on key questions and guidelines, https://www.politico.eu/wp-content/uploads/2019/11/Conference-on-the-Future-of-Europe.pdf [dostęp 20 lutego 2010 r.].

11 Szerzej zob. M. Skrzyńska, op. cit., s. 11-14.

12 Ibidem, s. 14-15. 
dów na temat prac konferencji. Dotyczą one: 1) statusu i celu działania konferencji (czym ma być konferencja w całokształcie procesu zmian; jaki kształt ma mieć deklaracja międzyinstytucjonalna w sprawie ustanowienia konferencji i jej prac; w jakim kierunku mają zmierzać jej prace - umocnienia elementów federalnych czy państw narodowych); 2) zakresu zadań, którymi konferencja powinna się zająć (czy i na ile włączać zagadnienia zmian instytucjonalnych, praworządności; jakie polityki czy sfery integracji powinny być przedmiotem szczególnej uwagi); 3) roli i zakresu zaangażowania poszczególnych instytucji w jej prace, (zwłaszcza) parlamentów narodowych oraz przedstawicieli społeczeństwa obywatelskiego; 4) sposobu przeprowadzania reform - przy wykorzystaniu obecnych traktatów (bez ich zmiany) albo zmiana traktatów.

\section{- Informacja o stanie prawa obowiązującego w Polsce w materii objętej treścią dokumentu UE}

Komunikat Komisji nie dotyczy konkretnych dziedzin czy aktów prawa krajowego. Materia w nim poruszana dotyczy integracji na poziomie europejskim (unijnym). Jego treść jest sformułowana na tyle ogólnie i postulatywnie, że trudno wiązać ją ze stanem prawa obowiązującego w Polsce.

\section{Ocena dokumentu UE}

- Ocena społecznych, gospodarczych i finansowych skutków dokumentu UE

Opiniowany komunikat, jako wkład Komisji Europejskiej w sformułowanie koncepcji konferencji w sprawie przyszłości Europy, ma charakter wewnętrzny (istotny w relacjach międzyinstytucjonalnych, gdyż skierowany jest tylko do Parlamentu Europejskiego i Rady) i nie wywołuje bezpośrednich skutków społecznych, gospodarczy i finansowych.

\section{- Ocena zgodności działań UE, o których mowa w dokumencie UE, z zasadą pomocniczości}

Komunikat nie podlega ocenie co do zgodności z zasadą pomocniczości w trybie protokołu nr 2, ponieważ nie jest projektem aktu ustawodawczego UE.

\section{Ustosunkowanie się do informacji Rady Ministrów}

Sejm RP skierował komunikat Komisji do Rady Ministrów 27 stycznia 2020 r. Rada Ministrów (Komitet do Spraw Europejskich) 14 lutego 2020 r. sformułowała stanowisko, które można streścić w następujących punktach: 1) „Rząd RP jest zdania, iż należy unikać założenia, że efektem Konferencji będą apele o ściślejszą integrację"; 2) celem konferencji nie powinno być przygotowanie zmian w traktatach, aczkolwiek Rada Ministrów podchodzi do tej kwestii z otwartością; 3) zasadą działania konferencji powinno być poszanowanie prerogatyw poszczególnych instytucji oraz równowagi instytucjonalnej, a także włączenie w jej dzia- 
łania (w tym w prace gremiów zarządczych) parlamentów narodowych; 4) zakres merytoryczny prac konferencji powinna wyznaczać Agenda strategiczna na lata 2019-2024; zarazem Rada Ministrów podkreśla potrzebę wykorzystania konferencji do prowadzenia refleksji nad przyszłością Europy w dłuższym czasie (10-20 lat); w ramach prac konferencji zagadnienia instytucjonalne powinny objąć także problem podziału kompetencji między Unię Europejską a państwa członkowskie (lepsze stosowanie zasady pomocniczości, konsekwencje instytucjonalne wyjścia Wielkiej Brytanii z Unii Europejskiej - kwestia braku równowagi głosów w Radzie); w odniesieniu do zagadnień materialnych rząd uważa za konieczne podjęcie namysłu nad przyszłością poszczególnych polityk sektorowych; 5) w kwestii organizacji konferencji rząd popiera propozycje Komisji Europejskiej, łącznie $\mathrm{z}$ aktywnym włączeniem różnych podmiotów, w tym partnerów społecznych, aczkolwiek zaznacza, że ustalenia w tym zakresie - jako wynik kompromisu międzyinstytucjonalnego - mogą odbiegać od propozycji Komisji Europejskiej; 6) zdaniem Rady Ministrów należy unikać automatyzmu we wdrażaniu konkluzji konferencji; rezultatem jej prac powinno być sprawozdanie przedłożone Radzie Europejskiej.

Odnosząc się do stanowiska Rady Ministrów, trzeba zwrócić uwagę na jego ogólnikowy charakter. Należy przyznać, że Rada Ministrów odnosiła się w nim do bardzo ogólnego w treści komunikatu Komisji, a ponadto, jak można wnosić z treści stanowiska, zależało jej na zachowaniu znaczącej swobody działania w sprawach, które będą podejmowane w ramach konferencji. Niemniej możliwe było przyjęcie bardziej konkretnego podejścia, jeśli weźmie się pod uwagę problemy wywoływane przez inne instytucje Unii Europejskiej czy państwa członkowskie i ich parlamenty. W szczególności należałoby oczekiwać, że w sposób względnie precyzyjny zostanie określony stosunek do statusu konferencji i jej relacji do traktatowych procedur zmian prawa pierwotnego. Konferencja ma być bowiem ciałem pozatraktatowym i o dość płynnej strukturze i niedookreślonym sposobie działania. Ponadto pojawia się pytanie: jaki - według Rady Ministrów cel miałaby mieć konferencja, skoro negatywnie wskazuje się, że nie powinna być nim tylko ściślejsza integracja, a także jeśli nie byłoby jej celem przygotowanie zmian w traktatach, to jaką miałyby przyjąć postać formalną? Nie ma też informacji na temat tego, które zagadnienia materialne Rada Ministrów uważa za priorytetowe z polskiej perspektywy. Natomiast za doniosły można uznać postulat wypracowania długofalowej wizji rozwoju Unii Europejskiej, aczkolwiek trzeba pamiętać, że 10-20 lat w polityce międzynarodowej z jej obecną dynamiką rozwojową to bardzo długo. Opracowywane wizje mogą być trudne do realizacji $\mathrm{w}$ radykalnie zmieniających się warunkach, ale nie oznacza to, że nie powinny być tworzone. 


\section{Opinia prawna}

\section{Podstawa prawna przyjęcia dokumentu UE}

Komunikat Komisji Europejskiej nie jest projektem aktu prawnego UE. Komisja skłania sie w nim do ustanowienia konferencji jako struktury, która nie ma wyraźnego umocowania $\mathrm{w}$ traktatach założycielskich. W dokumencie tym nie określa się także jej stosunku do znanego z art. 48 ust. 3 Traktatu o Unii Europejskiej Konwentu Europejskiego, czyli forum mającego przygotować reformy Unii Europejskiej o poważniejszym zakresie i większej wadze. Do pewnego stopnia konferencję można traktować jako strukturę o charakterze konsultacyjnym, w istocie poprzedzającą zwołanie Konwentu, o którym mowa w art. 48 ust. 2 Traktatu o Unii Europejskiej.

\section{Skutki prawne dokumentu UE}

Komunikat, jako dokument UE niebędący projektem aktu prawnego UE, nie wywołuje skutków prawnych w świetle zarówno prawa polskiego, jak i prawa unijnego.

\section{Kwestie proceduralne}

\section{- Procedura przyjmowania dokumentu UE}

Przyjmowanie komunikatu nie jest związane z zachowaniem określonej, wynikającej z prawa traktatowego, procedury. Komisja Europejska przyjęła omawiany komunikat 22 stycznia 2020 r. Do Sejmu dokument został przekazany 23 stycznia $2020 \mathrm{r}$.

Komunikat, jako dokument niebędący projektem aktu ustawodawczego UE, nie podlega ocenie zgodności z zasadą pomocniczości w trybie protokołu (nr 2) w sprawie stosowania zasad pomocniczości i proporcjonalności.

\section{- Działania Komisji do Spraw Unii Europejskiej}

Komisja do Spraw UE, uwzględniając art. 3 ust. 2 ustawy z dnia 8 października 2010 r. o współpracy Rady Ministrów z Sejmem i Senatem w sprawach związanych z członkostwem Rzeczypospolitej Polskiej w Unii Europejskiej (Dz.U. 2010, nr 213, poz. 1395), zwróciła się 27 stycznia 2020 r. do Rady Ministrów o przedstawienie informacji na temat komunikatu. Komisja do Spraw UE nie jest ograniczona terminami poza tymi, które mogą wynikać z celowości podejmowanych przez nią działań.

\section{Podsumowanie}

Komunikat Komisji Europejskiej w sprawie konferencji na temat przyszłości Europy jest wkładem $\mathrm{w}$ dyskusję międzyinstytucjonalną dotyczącą zwołania konferencji, jej funkcjonowania oraz rezultatów jej działalności. W tym kontekście 
jest dokumentem roboczym, a nie docelowym, który wywoływałby konieczność zajęcia bardziej jednoznacznego i odnoszącego się do wielu aspektów stanowiska. Kluczowe znaczenie będzie miał projekt deklaracji międzyinstytucjonalnej w sprawie konferencji.

\section{Bibliografia}

Mik C., Opinia na temat komunikatu Komisji Europejskiej zatytułowanego Biała ksiegga wsprawie przyszłości Europy. Refleksje iscenariusze dla UE-27 do 2025 [COM(2017) 2025 final], ,Zeszyty Prawnicze” 2017, nr 2(54), https://doi.org/10.31268/zpbas.2019.66. 